\title{
Nutrient-stimulated gallbladder emptying is incomplete during critical illness as assessed by $3 \mathrm{D}$ ultrasound
}

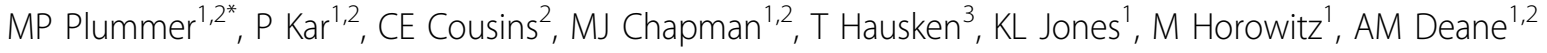 \\ From ESICM LIVES 2015 \\ Berlin, Germany. 3-7 October 2015
}

\begin{abstract}
Introduction
Gallbladder dysmotility has been implicated as a putative mechanism underlying acute acalculous cholecystitis and lipid malabsorption in the critically ill, despite nutrient-stimulated gallbladder emptying never having been quantified in this population. In health, endogenous cholecystokinin (CCK) stimulates gallbladder emptying.
\end{abstract}

\section{Objectives}

To determine fasting and nutrient-stimulated gallbladder volumes in critically ill patients.

\section{Methods}

Twenty-four critically ill patients (16M:8F, age $54 \pm 16 \mathrm{y}$, BMI $29 \pm 6 \mathrm{~kg} / \mathrm{m}^{2}$, APACHE II $17 \pm 5$, SOFA score 7.5 \pm 4 , day of admission $5 \pm 4$ ) with no history of biliary pathology were compared to 12 healthy volunteers (8M:4F, age $55 \pm 19$, BMI $24 \pm 4$ ). All participants were fasted for 8 hours and had a feeding catheter inserted into the duodenum. At $\mathrm{T}=-30 \mathrm{~min} 3 \mathrm{D}$ images of the gallbladder were acquired and wall thickness and presence of sludge recorded. Between $\mathrm{T}=0-120 \mathrm{~min} 20 \%$ intralipid was infused into the duodenum at $2 \mathrm{kcal} / \mathrm{min}$. Ultrasound measurements of the gallbladder were obtained at $30 \mathrm{~min}$ intervals until $\mathrm{T}=180 \mathrm{~min}$. Ejection fraction (\%) and the change in gallbladder volume (mls) were calculated from $\mathrm{T}=0-120 \mathrm{~min}$. Blood samples were taken at 30 minute intervals for the measurement of plasma CCK. Differences between groups were analysed using Student's t-test or Mann-Whitney test as appropriate and data are presented as mean (SD) or median [IQR]. Unadjusted correlation analyses were performed for demographic, ultrasound and CCK data.

\section{Results}

The cohorts were well matched for age, but BMI was greater $(\mathrm{P}<0.01)$ in the critically ill. In the critically ill, fasting gallbladder volumes were greater (by about three fold) [ICU 60[38-90] vs health 22[15-24] $\mathrm{ml}$; $\mathrm{P}<0.001$ ], as was wall thickness [0.44(0.14) vs $0.26(0.08) \mathrm{mm} ; \mathrm{P}<0.001]$. Sludge was evident in the majority $(71 \%)$ of patients but in none of the healthy participants. The ejection fraction was less in the critically ill [50[10-82] vs 77[72-82]\%; $\mathrm{P}=0.01$, but there was no difference in the change in gallbladder volume [22[11-32] vs 16[12-20]ml; P = 0.18]. Gallbladder volumes post lipid infusion $(\mathrm{T}=120 \mathrm{~min})$ were much greater in the critically ill [22[9-66] vs $4[3-6] \mathrm{ml} ; \mathrm{P}<0.01]$. There was no difference in fasting CCK concentration [ICU 5.3(2.5) vs health 4.7(1.2) pmol/L; P $=0.5$ ] or the incremental increase in plasma CCK T0-120 min [5.8(3.8) vs $4.6(3.7) \mathrm{pmol} / \mathrm{L} ; \mathrm{P}=0.37$ ]. There were no associations between fasting CCK concentration and fasting gallbladder volume, and CCK increment and gallbladder ejection fraction in the critically ill. There was an association between severity of illness score and gallbladder ejection fraction $[\mathrm{r}=-0.5 ; \mathrm{P}<0.05]$.

\section{Conclusions}

When fasted, critically ill patients appear to have larger and thicker walled gallbladder than healthy subjects. In response to nutrient stimulation the change in gallbladder volume is unaffected, but the ejection fraction is less leading to incomplete emptying. 


\section{Grant Acknowledgment}

Study supported by a NHMRC Postgraduate Scholarship.

\section{Authors' details}

${ }^{1}$ University of Adelaide, School of Medicine, Adelaide, Australia. ${ }^{2}$ Royal

Adelaide Hospital, Intensive Care Unit, Adelaide, Australia. ${ }^{3}$ Haukeland

University Hospital, Department of Medicine, Bergen, Norway.

Published: 1 October 2015

doi:10.1186/2197-425X-3-S1-A285

Cite this article as: Plummer et al: Nutrient-stimulated gallbladder emptying is incomplete during critical illness as assessed by 3D ultrasound. Intensive Care Medicine Experimental 2015 3(Suppl 1):A285.

\section{Submit your manuscript to a SpringerOpen ${ }^{\odot}$ journal and benefit from:}

- Convenient online submission

- Rigorous peer review

- Immediate publication on acceptance

- Open access: articles freely available online

- High visibility within the field

- Retaining the copyright to your article

Submit your next manuscript at $>$ springeropen.com 